\title{
10. (virtuálne) stretnutie zástupcov centier pre plúcnu artériovú hypertenziu
}

\author{
Správa z odborného podujatia
}

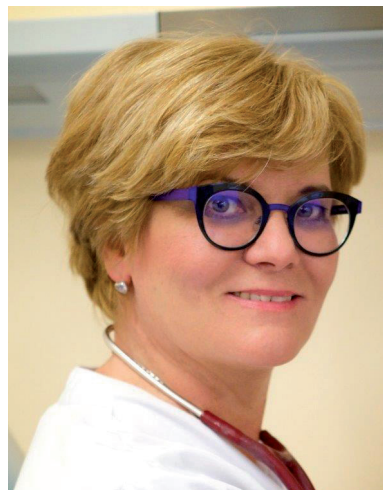

Doc. MUDr. Eva Goncalvesová CSc., FESC

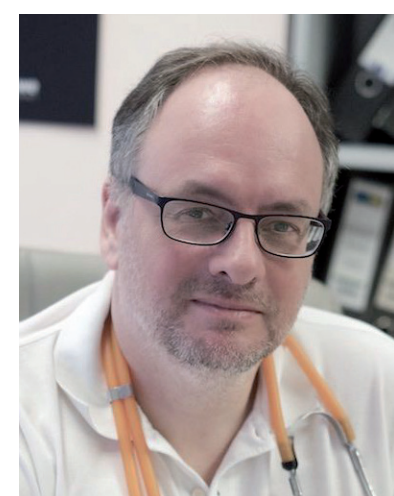

MUDr. Milan Luknár, PhD.

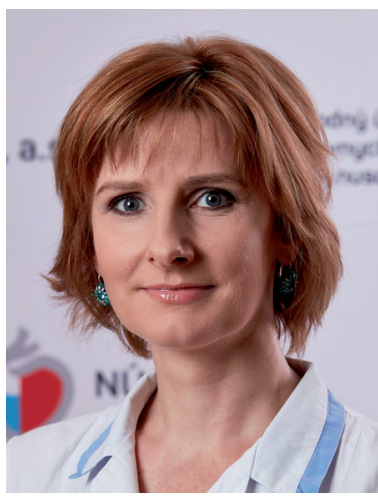

PhDr. Gabriela Šuttová

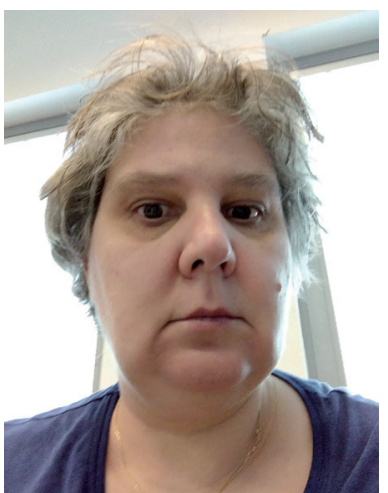

MUDr. Bibiána Kafková

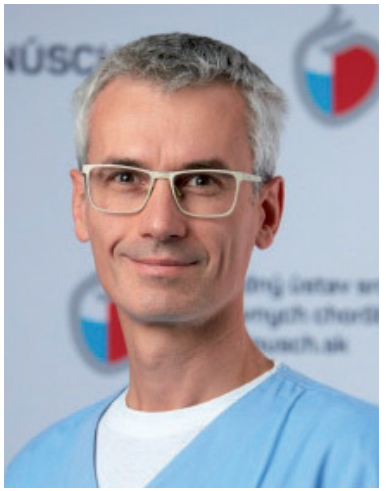

MUDr. Martin Záhorec, PhD.

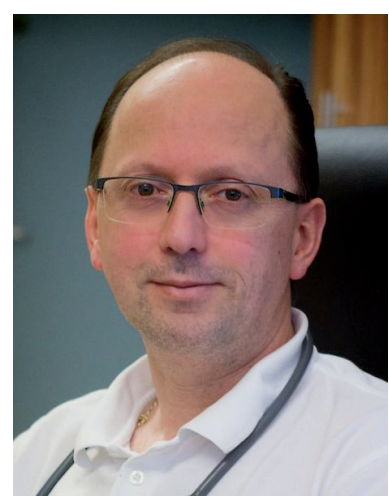

MUDr. Peter Lesný, PhD.

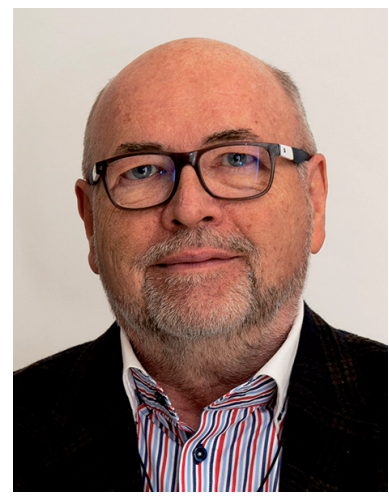

MUDr. Pavel Kmeč

Dňa 22. októbra 2020 sa uskutočnilo 10. stretnutie zástupcov referenčných centier pre plúcnu artériovú hypertenziu (PAH) z Bratislavy, Košíc a Banskej Bystrice. Vzhladom na súčasnú nepriaznivú epidemiologickú situáciu, ktorá obmedzuje fyzické stretnutia a živú osobnú diskusiu, sa účastníci stretli vo virtuálnom priestore prostredníctvom počítačovej aplikácie.

Plúcna hypertenzia $(\mathrm{PH})$ je stav, pri ktorom sa v plúcnici nameria zvýšený tlak. PH je spoločným nálezom pri množstve ochorení a stavov, ktoré môžu byt' etiologicky, klinicky, terapeuticky a prognosticky rozdielne. Jednou zo skupín plúcnej hypertenzie je PAH. Drobné plúcne tepny sú postihnuté

nadmernou vazokonstrikciou, proliferáciou a trombózou. Tieto patologické zmeny vedú $\mathrm{k}$ zníženiu celkového priesvitu plúcneho artériového riečiska, vzostupu plúcnej vaskulárnej rezistencie, tlakovému pretaženiu a zlyhaniu pravej komory. PAH má zriedkavý výskyt, progredujúci charakter a dodnes ju nevieme vyliečit pomocou farmakoterapie. Jedinou kuratívnou možnostou ostáva transplantácia plúc. Diagnostika PAH je náročná a vyžaduje si absolvovanie vel'kého počtu neinvazívnych aj invazívnych vyšetrení. Preto by sa mala starostlivost' o pacientov s touto chorobou sústredovat' do špecializovaných centier s dostupnostou širokého spektra vyšetrovacích metód a liečebných postupov. 


\begin{tabular}{|c|c|c|c|c|c|}
\hline \multirow[t]{11}{*}{1} & \multirow[t]{11}{*}{ PAH } & 1.1. & \multirow{3}{*}{\multicolumn{3}{|c|}{$\begin{array}{l}\text { idiopatická } \\
\text { hereditárna } \\
\text { indukovaná liekmi a toxínmi }\end{array}$}} \\
\hline & & 1.2 . & & & \\
\hline & & 1.3. & & & \\
\hline & & \multirow[t]{5}{*}{1.4.} & \multirow[t]{5}{*}{ asociovaná s } & 1.4 .1 & ochoreniami spojiva \\
\hline & & & & 1.4 .2 & infekciou HIV \\
\hline & & & & 1.4 .3 & portálnou hypertenziou \\
\hline & & & & 1.4 .4 & vrodenými chybami srdca \\
\hline & & & & 1.4 .5 & schistozomiázou \\
\hline & & 1.5 . & \multirow{3}{*}{\multicolumn{3}{|c|}{$\begin{array}{l}\text { PAH s dlhodobou odpoved’ou na kalciové blokátory } \\
\text { s črtami venózneho alebo kapilárneho postihnutia } \\
\text { perzistujúca plúcna hypertenzia novorodencov }\end{array}$}} \\
\hline & & 1.6. & & & \\
\hline & & 1.7. & & & \\
\hline \multirow[t]{4}{*}{2} & \multirow[t]{4}{*}{ PH pri postihnutí lavého srdca } & 2.1 & \multicolumn{3}{|c|}{ pri srdcovom zlyhávaní so zachovanou ejekčnou frakciou lavej komory } \\
\hline & & 2.2 & \multicolumn{3}{|c|}{ pri srdcovom zlyhávaní so zníženou ejekčnou frakciou lavej komory } \\
\hline & & 2.3 . & \multicolumn{3}{|c|}{ chlopňové chyby } \\
\hline & & 2.4 & \multicolumn{3}{|c|}{ vrodené/získané stavy vedúce $\mathrm{k}$ postkapilárnej $\mathrm{PH}$} \\
\hline \multirow[t]{5}{*}{3} & PH pri ochorení plúc alebo hypoxii & 3.1 & \multicolumn{3}{|c|}{ obštrukčné choroby plúc } \\
\hline & & 3.2 & \multicolumn{3}{|c|}{ reštrikčné choroby plúc } \\
\hline & & 3.3 . & \multicolumn{3}{|c|}{ iné choroby so zmiešaným obrazom reštrikcie a obštrukcie } \\
\hline & & 3.4 & \multicolumn{3}{|c|}{ hypoxia bez ochorenia plúc } \\
\hline & & 3.5. & \multicolumn{3}{|c|}{ vývojové chyby plúc } \\
\hline \multirow[t]{2}{*}{4} & PH pri obštrukciách plúcnice & 4.1 & \multicolumn{3}{|c|}{ chronická tromboembolická $\mathrm{PH}$} \\
\hline & & 4.2. & \multicolumn{3}{|c|}{ iné obštrukcie plúcnice } \\
\hline \multirow[t]{4}{*}{5} & PH s nejasným alebo multifaktoriálnym mechanizmom & 5.1. & \multicolumn{3}{|c|}{ hematologické choroby } \\
\hline & & 5.2. & \multicolumn{3}{|c|}{ systémové a metabolické ochorenia } \\
\hline & & 5.3 & \multicolumn{3}{|l|}{ iné } \\
\hline & & 5.4 & \multicolumn{3}{|c|}{ komplexné vrodené chyby srdca } \\
\hline
\end{tabular}

PH - plúcna hypertenzia; PAH - plúcna artériová hypertenzia

V Slovenskej republike (SR) sa problematikou PAH zaoberajú viaceré centrá: $\mathrm{v}$ Národnom ústave srdcových a cievnych chorôb (NÚSCH) v Bratislave sú to Centrum pre PAH pri Oddelení zlyhávania a transplantácie srdca zamerané na celé spektrum PH, Centrum pre vrodené chyby srdca v dospelosti, ktoré sa špecializuje na problematiku $\mathrm{PAH}$ pri vrodených chybách a chronickú tromboembolickú PH a Detské kardiocentrum so zameraním na $\mathrm{PH}$ v detskom veku. Okrem toho fungujú centrá pre PAH v Stredoslovenskom ústave srdcových a cievnych chorôb (SÚSCCH) v Banskej Bystrici a Východoslovenskom ústave srdcových chorôb (VÚSCH) v Košiciach. NÚSCH Bratislava sa stal pridruženým členom European Reference Network - ERN-LUNG. ERN-LUNG je siet poskytovatelov zdravotnej starostlivosti a pacientskych organizácií z Európy, ktorá sa zaoberá zriedkavými chorobami plúc. Orientuje sa na pacienta a má za ciel' redukovat morbiditu a mortalitu na zriedkavé ochorenia plúc.

Stretnutie viedla doc. MUDr. Eva Goncalvesová CSc., FESC, prednostka Kardiologickej kliniky LFUK a NÚSCH $\mathrm{v}$ Bratislave.

MUDr. Milan Luknár, PhD., vedúci lekár Centra pre PAH pri Oddelení zlyhávania a transplantácie srdca NÚSCH informoval o nových poznatkoch, o ktorých diskutovalo 6. svetové sympózium o PH v vo francúzskom Nice v roku
2018. Upozornil na vybrané aspekty, v ktorých nastal posun od publikovania ostatných Odporúčaní pre manažment plúcnej hypertenzie (2015).

Pracovná skupina pre diagnostiku vypracovala novú klinickú klasifikáciu PH (tabulka 1). Samostatnou podskupinou skupiny I PH (t. j. PAH) sa stala $\mathrm{PAH}$ reagujúca na kalciové blokátory. Pacienti s týmto typom PAH majú dobrú dlhodobú prognózu. Zásadnou zmenou prešla definícia a hemodynamická klasifikácia (tabulka 2), v ktorej sa hranica

Tabulka 2 Hemodynamická klasifikácia PH a jej vztah ku klinickej klasifikácii (1)

\begin{tabular}{lll}
\hline Definícia & Charakteristika & Klinická skupina \\
\hline Prekapilárna & $\mathrm{mPAP}>20 \mathrm{mmHg}$ & $1,3,4,5$ \\
& $\mathrm{PAWP} \leq 15 \mathrm{mmHg}$ & \\
& $\mathrm{PVR} \geq 3 \mathrm{~W} . \mathrm{j}$. \\
\hline Izolovaná postkapilárna & $\mathrm{mPAP}>20 \mathrm{mmHg}$ & 2,5 \\
& $\mathrm{PAWP}>15 \mathrm{mmHg}$ \\
& $\mathrm{PVR}<3 \mathrm{~W} . \mathrm{j}$. \\
\hline Kombinovaná post- & $\mathrm{mPAP}>20 \mathrm{mmHg}$ & 2,5 \\
a prekapilárna & $\mathrm{PAWP}>15 \mathrm{mmHg}$ & \\
& $\mathrm{PVR} \geq 3 \mathrm{~W} . \mathrm{j}$. & \\
\hline
\end{tabular}

mPAP - stredný tlak v plúcnici, PAWP - tlak v plúcnici v zaklinení, PVR plúcna vaskulárna rezistencia 
$\mathrm{PH}$ výrazne znížila. Zmeny vychádzajú z prác, ktoré sa zaoberali invazívnym meraním tlaku v plúcnici u zdravých ludí. Ukázalo sa, že normálny stredný tlak v plúcnici má hodnotu $14 \pm 3 \mathrm{mmHg}$. Po pripočítaní dvoch smerodajných odchýlok $\mathrm{k}$ strednej hodnote sa za hornú hranicu normy považuje hodnota $20 \mathrm{mmHg}$ a vyššie hodnoty sa hodnotia ako $\mathrm{PH}$. Okrem toho, stredný tlak v plúcnici 21 až $24 \mathrm{mmHg}$ sa spája $s$ horšou prognózou. Pri kontrolnom invazívnom vyšetrení s časovým odstupom sa takéto hodnoty stredného tlaku v plúcnici často posúvajú nad $25 \mathrm{mmHg}$, čo je hranica $\mathrm{PH}$ aj podla doterajších kritérií. Zmeny sa udiali aj v definícii kombinovanej post- a prekapilárnej PH. Za kombinovanú post- a prekapilárnu $\mathrm{PH}$ sa považuje $\mathrm{PH}$ s tlakom v zaklinení $>15 \mathrm{mmHg}$ a súčasne plúcnou vaskulárnou rezistenciou $>3$ Woodove jednotky. Tento ukazovatel' odráža prítomnost' tzv. plúcnej vaskulárnej choroby, ktorá zodpovedá za prekapilárnu zložku PH.

$\mathrm{PH}$ sa často vyskytuje pri postihnutí oddielov lavého srdca. Odhalenie PH pri systolickej dysfunkcii lavej komory (LK) a chybách aortálnej a mitrálnej chlopne je pomerne jednoznačné. Komplexnejšiu situáciu predstavuje $\mathrm{PH}$ pri diastolickej dysfunkcii LK, ktorá môže mat podobný echokardiografický aj katetrizačný nález ako PAH. Navrhuje sa nová klasifikácia hypertenzie pri postihnutí lavého srdca (tabulka 2), ktorá vychádza z invazívneho potvrdenia. Nevyhnutným predpokladom je presné meranie tlaku v plúcnici v zaklinení. U pacientov so znakmi vyššej tzv. neinvazívnej pravdepodobnosti tohto typu PH (napríklad staršie osoby, ženské pohlavie, fibrilácia predsiení, hypertrofia lavej komory, dilatácia lavej predsiene, obraz diastolickej dysfunkcie L'K), ktorú niektorí autori nazývajú aj „PH s kardiovaskulárnymi rizikovými faktormi“, sa pri hraničných hodnotách tlaku v zaklinení (13 až $15 \mathrm{mmHg}$ ) odporúčajú provokačné testy, napríklad intravenózna infúzia $500 \mathrm{ml}$ fyziologického roztoku v priebehu 10 minút. Za dôkaz PH pri diastolickej dysfunkcii LK sa predpokladá vzostup tlaku v zaklinení nad $18 \mathrm{mmHg}$. Štúdie z ostatného obdobia nepreukázali prospešnosť špecifickej liečby tohto typu PH.

$\mathrm{K}$ rozvoju PAH predisponujú aj niektoré ochorenia spojiva, najmä systémová skleróza. Svetové sympózium vydalo odporúčanie aj pre skríning PAH u pacientov so systémovou sklerózou. Ročný skríning sa odporúča u pacientov s difúznou kapacitou plúc pre oxid uholnatý (DLCO) < 80 \% predikovaných hodnôt. Za vhodné skríningové nástroje sa považujú viaceré algoritmy: DETECT, postup podla odporúčaní Európskej kardiologickej spoločnosti, pomer percentuálnych hodnôt funkčnej vitálnej kapacity plúc a difúznej kapacity pre oxid uholnatý $>1,6$, hodnota NT-proBNP presahujúca dvojnásobok horného limitu.

Špecifická liečba $\mathrm{PH}$ pri postihnutí lavostranných srdcových oddielov a $\mathrm{PH}$ pri ochorení plúc s alveolárnou hypoxiou (tradičné „cor pulmonale“) sa nad’alej neodporúča, kedže chýbajú dôkazy pre jej prospešnost'. Cielená, tzv. špecifická liečba, je indikovaná v prípade $\mathrm{PAH}$ a vo vybraných prípadoch chronickej tromboembolickej $\mathrm{PH}$. V terapii dominuje kombinačná farmakoterapia, iniciálna monoterapia je vhodná už len u vybraných pacientov s nízkym rizikom mortality. Vol'ba terapeutického postupu vychádza z rizikových skórovacích systémov. Kedže systém hodnotenia rizika podla Európskej kardiologickej spoločnosti je pomerne zložitý a subjektívny, viaceré tímy sa pomocou retrospektívnych analýz registrov PAH pokúsili o jeho zjednodušenie a kvantifikáciu rizika. Švédski a nemeckí autori kombinujú vybrané invazívne, neinvazívne a funkčné ukazovatele prognózy (napríklad funkčná trieda podla Svetovej zdravotníckej organizácie, NT-proBNP, plochu pravej predsiene, tlak v pravej predsieni, prítomnost' perikardiálneho výpotku, kardiálny index, kyslíkovú saturáciu zmiešanej artériovej krvi z plúcnice, šestminútový test chôdzou). Najlepšiu prognózu mali pacienti, ktorí si pri kontrolnom vyšetrení zachovávali stav nízkeho rizika mortality, respektíve sa pri liečbe dostali do pásma nízkeho rizika. Francúzski autori zvolili inú metodiku. Sledovali počet kritérií nízkeho rizika (funkčná trieda I alebo II, výsledok šesṫminútového testu chôdzou $>440 \mathrm{~m}$, tlak v pravej predsieni $<8 \mathrm{mmHg}$, kardiálny index $\geq 2,5 \mathrm{l} / \mathrm{min} / \mathrm{m}^{2}$, respektíve NT-proBNP $<300 \mathrm{ng} / \mathrm{ml}$ ako náhrada invazívnych ukazovatelov). Počet kritérií nízkeho rizika pri liečbe súvisel s prognózou - najlepšie prežívanie mali pacienti, ktorí dosiahli všetky ukazovatele nízkeho rizika. Nasledujúce odporúčania pre liečbu PAH by teda mohli obsahovat' schému, ktorá by mohla hodnotenie rizika mortality zjednodušit a objektivizovat'. Treba poznamenat', že dôkazy pre účinnost' liečby pri strednom tlaku > $20 \mathrm{mmHg}$ (t. j. pri novej definícii PAH) z prospektívnych randomizovaných a kontrolovaných štúdií stále nie sú $\mathrm{k}$ dispozícii. Dr. Luknár na záver uviedol, že bez ohladu na to sa však zdá, že klúčovým determinantom úspešnosti liečby PAH je dosiahnutie, respektíve zachovanie si nízkeho rizika mortality. U všetkých pacientov, ktorí stav nízkeho rizika nedosiahnu, sa odporúča eskalovat liečbu formou kombinácie a pridania parenterálneho prostanoidu. Dr. Luknár navrhol, aby sa u novodiagnostikovaných pacientov pri prvom komplexnejšom kontrolnom vyšetrení, ktoré by sa malo uskutočnit do 3 - 4 mesiacov od iniciácie liečby, stanovila prítomnost' parametrov priaznivej prognózy u jednotlivých pacientov podla Francúzskeho registra (funkčná trieda I-II, šest'minútový test chôdzou $>440 \mathrm{~m}$, respektíve NT-proBNP $<300 \mathrm{ng} / \mathrm{ml}$ ). Ak sa nedosiahne prítomnost’ väčšiny parametrov dobrej prognózy, odporúča zvážit eskaláciu liečby.

MUDr. Bibiána Kafková z Východoslovenského ústavu srdcových a cievnych chorôb oboznámila účastníkov s organizáciou starostlivosti o pacientov s PAH v ich centre. Do centra sú pacienti poukazovaní ambulantnými kardiológmi, pneumológmi, ako aj z interných a plúcnych oddelení. Pred poukázaním pacienti obvykle absolvujú základné vyšetrenia, ako je pneumologické zhodnotenie vrátane funkčného vyšetrenia plúc a zobrazovacie vyšetrenia (CT, ventilačno- 
-perfúzna scintigrafia). „Jadro“ centra tvoria špecializovaní kardiológovia so skúsenostami s echokardiografiou, sestry a psychológ. Títo spolupracujú s lôžkovými a invazívnymi oddeleniami VÚSCH, ako aj plúcnymi, rádiodiagnostickými a dalšími pracoviskami, ktoré realizujú príslušné vyšetrenia $\mathrm{v}$ rámci diagnostického algoritmu (lavostranná katetrizácia s meraním koncovodiastolického tlaku v LK, pravostranná katetrizácia). Súčastou algoritmu je záverečné diagnostické zhodnotenie a riziková stratifikácia. Rozhodnutie o liečbe prijímajú dvaja lekári. Parenterálna liečba sa zvyčajne iniciuje počas hospitalizácie. Ďalšie sledovanie sa vykonáva s mesačnými intervalmi vo forme telefonického kontaktu či novšími komunikačnými nástrojmi (napríklad WhatsApp), kedy sa podla stavu stanoví urgencia fyzickej kontroly. Každých tri až šest̉ mesiacov sa vykoná komplexnejšia klinická kontrola vrátane fyzikálneho vyšetrenia, merania vitálnych funkcií, kyslíkovej saturácie, laboratórnych vyšetrení vrátane NT-proBNP, echokardiografie a objektivizácie fyzickej výkonnosti. Zhodnotí sa riziko a rozhodne sa o potrebe katetrizácie, respektíve eskalácie liečby.

MUDr. Peter Lesný, PhD., z Centra pre PAH pri Oddelení zlyhávania a transplantácie srdca NÚSCH priblížil princípy dlhodobého sledovania pacientov s PAH v uvedenom centre.

$\mathrm{V}$ rámci pravidelných návštev je potrebné zodpovedat' nasledovné otázky: Nastalo od ostatnej návštevy klinické zhoršenie? Možno prípadné zhoršenie pripísat samotnej $\mathrm{PAH}$, alebo skôr pridruženým ochoreniam? Je funkcia pravej komory stabilná a dobrá? Je aktuálny stav kompatibilný s dobrou prognózou? Jedným zo zásadných cielov dlhodobého sledovania je teda zhodnotit dynamiku ochorenia so zretelom na riziko mortality, aby bolo možné na zhoršenie prognózy reagovat úpravou terapeutického postupu. Odporúča sa využit niektorú zo schém rizikovej stratifikácie. Cielom terapeutických opatrení je dosiahnut', aby sa väčšina hodnôt sledovaných ukazovatelov nachádzala v pásme nízkeho rizika. Prvá návšteva sa uskutočňuje približne mesiac po iniciácii liečby, okrem reakcie na liečbu a jej subjektívnej tolerancie sa zistujú aj prípadné nežiaduce účinky. $\mathrm{V}$ d’alšom priebehu sa každé tri mesiace strieda tzv. „malä“ kontrola s tzv. „velkou", podrobnejšou. Dr. Lesný upozornil na aspekt kontroly sérovej koncentrácie železa u pacientov s PAH. Izolovaná sideropénia bez anémie je u nich bežná a môže sa spájat so zníženou funkčnou kapacitou. $\mathrm{V}$ indikovaných prípadoch sa môže železo substituovat parenterálnou formou. Plán a rozsah kontrolných vyšetrení v uvedenom centre, ako aj porovnanie s odporúčaniami Európskej kardiologickej spoločnosti zobrazuje tabulka 3.

PhDr. Gabriela Šuttová, vedúca sestra Centra pre PAH pri Oddelení zlyhávania a transplantácie srdca NÚSCH, informovala o špecifikách ambulantnej starostlivosti o pacientov liečených treprostinilom. Treprostinil je termostabilný analóg prostacyklínu. V súčasnosti máme na Slovensku dve možnosti podávania treprostinilu: subkutánna aplikácia pomocou externej pumpy a intravenózna aplikácia pomocou plne implantovatel'nej pumpy. Výhodou subkutánneho podávania je jednoduchá aplikácia a možnost̉ pohotovej úpravy dávky, ktorú môže vykonat aj sám pacient. Nevýhodou je predovšetkým lokálna bolestivost̉ počas niekolkých dní po výmene subkutánnej kanyly. Implantovatelná pumpa si síce vyžaduje chirurgickú implantáciu a dopĺňanie prípravku lekárom $\mathrm{v}$ pravidelných intervaloch, odpadá však lokálna bolestivost', dlhodobé narušenie kožného krytu pri aplikovanej kanyle a nevyhnutnost' neustáleho nosenia extrakorporálnej pumpy. Kvalita života je vyššia. Z toho vyplývajú aj špecifiká dlhodobej ošetrovatel'skej starostlivosti. Klúčovú úlohu má edukácia pacienta, ktorý v prípade subkutánneho podávania musí ovládat výmenu a aplikáciu podkožnej kanyly, plnenie zásobníka s prípravkom, manipuláciu s pumpou a základné riešenie urgentných situácií. Podmienkou liečby pomocou plne implantovatelnej pumpy je absolútna kompliancia pacienta, ktorý sa musí bezpodmienečne dostavit na lekárske kontroly v pravidelných intervaloch. Dávka lieku sa upravuje pomocou zmeny koncentrácie pri doplňaní pumpy (obrázok 1). Dr. Šuttová na konkrétnych prípadoch ilustrovala

Tabulka 3 Dlhodobé sledovanie pacientov - odporúčania Európskej kardiologickej spoločnosti (3) verzus klinická prax v Centre pre PAH pri Oddelení zlyhávania a transplantácie srdca Národného ústavu srdcových a cievnych chorôb v Bratislave

\begin{tabular}{|c|c|c|c|c|}
\hline \multirow[b]{2}{*}{ Vyšetrenie } & \multicolumn{2}{|c|}{ Odporúčania } & \multicolumn{2}{|c|}{ Naša prax } \\
\hline & à $3-6$ mesiacov & à $6-12$ mesiacov & à 3 mesiace & à 6 mesiacov \\
\hline Lekárske vyšetrenie a stanovenie funkčnej triedy & + & + & + & \\
\hline Elektrokardiogram & + & + & + & \\
\hline Test chôdzou/Borgovo skóre dyspnoe & + & + & & + \\
\hline Spiroergometria & & + & & \\
\hline Echo & & + & & + \\
\hline $\begin{array}{l}\text { Základné laboratórne (krvný obraz, INR, Na, K, AST, ALT, bilirubín } \\
\text { kreatinín, NT-proBNP) }\end{array}$ & + & + & + & \\
\hline Rozšírené laboratórne (TSH, troponín, Fe status + individuálne) & & + & & + \\
\hline Analýza krvných plynov & & + & & + \\
\hline Pravostranná srdcová katetrizácia & & + & & individuálne \\
\hline
\end{tabular}




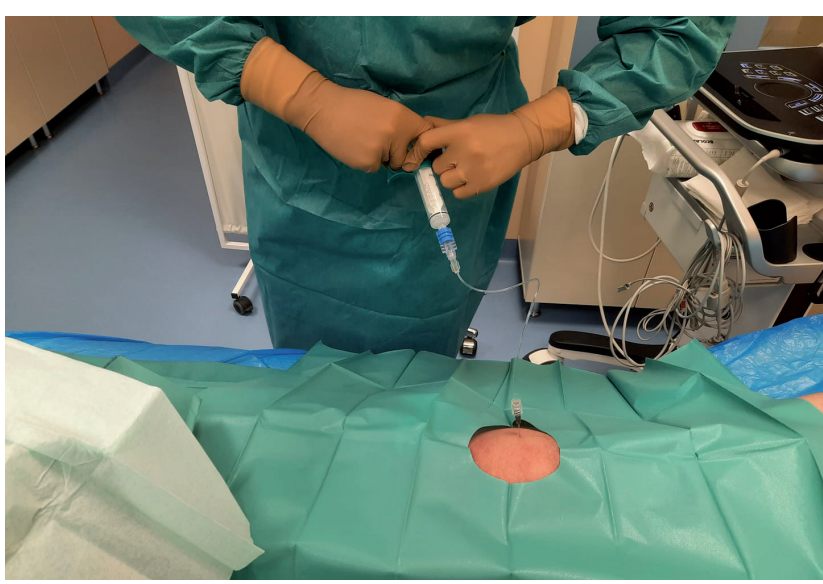

Obrázok 1 Plnenie plne implantovatelnej podkožnej pumpy na intravenózne podávanie treprostinilu n

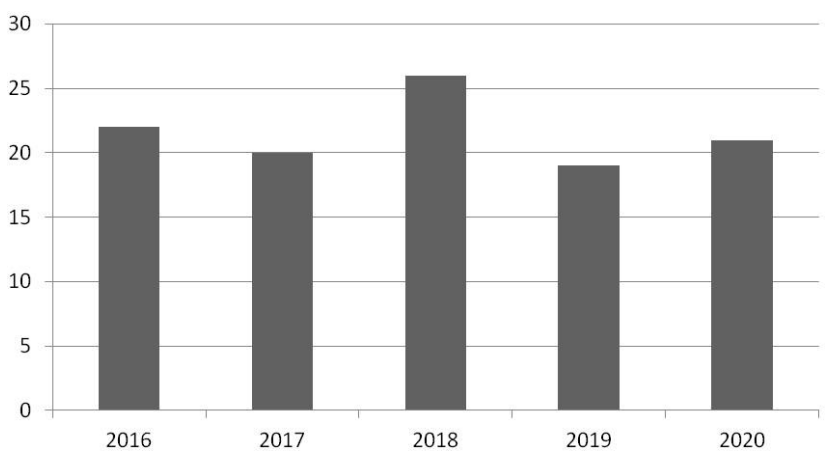

Obrázok 2 Prevalencia PAH na základe informácií centier pre PH v Slovenskej republike. Chýbajú informácie za Centrum pre vrodené chyby $\mathbf{v}$ dospelosti Národného ústavu srdcových a cievnych chorôb $v$ Bratislave starostlivost’ o pacienta s pumpou $\mathrm{v}$ ambulancii centra pre $\mathrm{PAH}$, ako aj problémové situácie, ktoré sa môžu u týchto pacientov vyskytnút.

MUDr. Martin Záhorec, PhD., primár Kardiologického oddelenia Detského kardiocentra (DKC) NÚSCH v Bratislave, uviedol, že register PAH DKC zahŕňa 29 detských pacientov (najčastejšie s vrodenou chybou srdca po operácii a komplexnými vrodenými chybami srdca) a 10 dospelých pacientov (najčastejšie s Eisenmengerovým syndrómom a komplexnými vrodenými chybami srdca po operácii). Z detí s $\mathrm{PAH}$ po intervencii je najviac (štyri) s diagnózou perzistujúci ductus arteriosus. Prevažná čast’ pacientov (86 \%) má lahké funkčné postihnutie (funkčná trieda I alebo II). Väčšina (61\%) pacientov je liečená kombinačnou duálnou alebo tripletnou liečbou. Treprostinil užívajú dvaja chorí. Dr. Záhorec uviedol tiež krátke kazuistiky pacientov s hereditárnou $\mathrm{PAH}$ a $\mathrm{PAH}$ asociovanou s vrodenou chybou srdca.

Dr. Luknár oboznámil účastníkov so základnými ukazovatelmi Centra pre PAH NÚSCH Bratislava. V evidencii je aktuálne 69 žijúcich pacientov, $\mathrm{z}$ toho traja s dlhodobo reverzibilnou PAH sú liečení kalciovými antagonistami. Za ostatný rok zomrelo pät pacientov, najčastejšie na progresívne zlyhávanie pravej komory a nekardiálne príčiny. Dvaja pacienti podstúpili úspešnú transplantáciu plúc v Prahe. Novodiagnostikovaných bolo spolu osem pacientov. Dr. Kafková informovala, že v centre pre PAH VÚSCH Košice evidujú 60 žijúcich pacientov, za ostatný rok zomrelo 10 pacientov a novodiagnostikovaných bolo 10 pacientov. Ako uviedol MUDr. Pavel Kmeč, vedúci lekár Centra pre PAH v Stredoslovenskom ústave srdcových a cievnych chorôb v Banskej Bystrici, toto centrum eviduje 30 žijúcich pacientov. Za ostatný rok bola diagnóza stanovená u troch pacientov a zomreli dvaja chorí. Dr. Kmeč uviedol príklad pacienta s idiopatickou PAH. Zdôraznil praktický význam prognostickej stratifikácie, ktorá sa uplatnila pri rozhodovaní o intenzite špecifickej farmakoterapie $\mathrm{PH}$.

Z uvedených informácií (chýbajú však údaje za d’alšie centrum pre PAH) je možné odhadnút približnú incidenciu idiopatickej PAH v Slovenskej republike, ktorá za uplynulý rok dosiahla minimálne 1,9 prípadov na milión obyvatelov. Incidenciu PAH v ostatných rokoch na základe informácií jednotlivých centier približuje obrázok 2 .

Účastníci stretnutia prediskutovali d’alšie aktuálne problémy v oblasti starostlivosti o pacientov s PAH v Slovenskej republike. Vyjadrili nespokojnost’ s pretrvávajúcim neúmerným zatažením administratívou, ktorá sa týka evidencie a úhrady špecifickej liečby PAH zo strany zdravotných poistovní. Administratíva si vyžaduje značné personálne a materiálové náklady a spája sa s rizikom oneskorenia iniciácie liečby. Riešením by bola elektronizácia a urýchlenie komunikácie so zdravotnými poistovňami. Odborníci tiež formulovali požiadavku na rozšírenie portfólia prípravkov v rámci špecifickej liečby PAH. Privítali by dostupnost’ tadalafilu, ktorý dokázal priaznivý vplyv na stav pacientov $\mathrm{s}$ PAH v monoterapii, ale ako jeden $\mathrm{z}$ mála perorálnych liekov aj prospešnost’ vzhladom na prognózu v rámci iniciálnej kombinovanej liečby. Konštatovali tiež, že transplantácia plúc pre slovenských pacientov je nad’alej možná, podporujú však zvýšenie jej dostupnosti zdokonalením transplantačného a darcovského programu a medzinárodnej spolupráce. Účastníci podporujú vznik registra $\mathrm{PH}$, kedže na rozdiel od iných európskych krajín nie sú k dispozícii globálne údaje o výskyte PAH, trendoch vývoja ochorenia a osude pacientov.

Doc. MUDr. Eva Goncalvesová, CSc., na záver navrhla úlohy na riešenie do budúceho stretnutia na jeseň 2021:

- prijatie jednotného stratifikačného systému rizika pacientov s PAH na Slovensku 
- požiadat poistovňu o definovanie podmienok na preskripciu tadalafilu

- zozbierat' údaje o prevalencii PAH a opísat' podrobnejšie epidemiológiu PAH v SR.

Jubilejné 10. stretnutie pracovníkov centier pre plúcnu hypertenziu dokázalo, že nemožnost’ stretnút sa osobne v súčasnej nepriaznivej epidemiologickej situácii nepredstavuje prekážku dlhodobej systematickej spolupráce a korektnej výmeny informácií. Centrá nad’alej pokračujú v praktickej činnosti, vedeckej práci a edukácii d’alších odborníkov. Cielom ostáva poskytnút našim pacientom so zriedkavým a smrtelným ochorením, plúcnou artériovou hypertenziou, starostlivost’ porovnatel'nú s európskym a svetovým štandardom.

MUDr. Milan Luknár, PhD. Centrum pre PAH pri Oddelení zlyhávania a transplantácie srdca, Národný ústav srdcových a cievnych chorôb, Bratislava

\section{Literatúra}

1. Simonneau G, Montani D, Celermajer DS, et al. Haemodynamic definitions and updated clinical classification of pulmonary hypertension. Eur Respir J. 2019;53:1801913.

2. Frost A, Badesch D, Gibbs JSR, et al. Diagnosis of pulmonary hypertension. Eur Respir J. 2019 Jan 24;53:1801904.

3. Galiè N, Humbert M, Vachiery JL, et al. 2015 ESC/ERS Guidelines for the diagnosis and treatment of pulmonary hypertension: The Joint Task Force for the Diagnosis and Treatment of Pulmonary Hypertension of the European Society of Cardiology (ESC) and the European Respiratory Society (ERS): Endorsed by: Association for European Paediatric and Congenital Cardiology (AEPC), International Society for Heart and Lung Transplantation (ISHLT). Eur Heart J 2016;37:67-119.

4. Vachiéry JL, Tedford RJ, Rosenkranz S, et al. Pulmonary hypertension due to left heart disease. Eur Respir J. 2019;53:1801897.

5. Galiè N, Channick RN, Frantz RP, et al. Risk stratification and medical therapy of pulmonary arterial hypertension. Eur Respir J. 2019;53:180188. 